\title{
践 New Disease Reports \\ First report of Serratia marcescens causing yellow wilt disease on sunflower in Russia
}

\author{
A.N. Ignatov ${ }^{1,2 *}$, M.V. Khodykina ${ }^{2}$, V.A. Polityko ${ }^{1}$ and M.V. Sukhacheva ${ }^{3}$ \\ ${ }^{1}$ Russian Institute of Phytopathology, Bolshie Vyazemy 143050, Russia; ${ }^{2}$ Russian People's Friendship University, Moscow \\ 117198, Russia; ${ }^{3}$ Institute of Bioengineering, Research Center of Biotechnology of the Russian Academy of Sciences, \\ Moscow, 117312 Russia
}

*E-mail: an.ignatov@gmail.com

Received: 06 Nov 2014. Published: 04 Feb 2016. Keywords: bacterial plant disease, Helianthus annuus

In August-September 2011, sunflower (Helianthus annuus) plants with yellow, wilted leaves were found in commercial fields in the Republic of North Osetia-Alania (North Caucasus region of Russia). Approximately $20 \%$ of the plants in the fields exhibited yellowing and wilting. Cross sections of stems near the affected leaves revealed a brown discoloration in the phloem. Isolations were made from the stems of 24 symptom-bearing sunflower plants collected from four different fields. Small tissue pieces $\left(2-4 \mathrm{~mm}^{3}\right)$ from the phloem were excised, surface sterilised, rinsed several times and ground. An aliquot of the slurry was plated onto yeast extractdextrose-calcium carbonate (YDC) agar. Isolates from sunflower plants were consistent with Serratia marcescens in colony colour, morphology and biochemical properties, as described by Schaad et al. (2001).

To determine the genetic diversity, partial sequences of the 16S rRNA gene and $r e c A$ gene were amplified using primer pairs 8F/1492R (Stackebrandt \& Liesack, 1993) and ErecAF/ErecAR (Young \& Park, 2007), respectively. Additionally, the bacterial isolates were tested by multiplex PCR with primers YV1/YV4, specific for S. marcescens, and a79F/R which amplifies only cucurbit yellow vine disease (CYVD)-causing strains (Zhang et al., 2005). The partial 16S rRNA gene sequences (GenBank Accession Nos. KT741016-KT741022) were 99\% identical to S. marcescens strains MG1 (AY498856) and JASM1 (KF528829). The recA gene sequences (KT780423-KT780430) were 98\% identical to S. marcescens (type strain ICMP 7617; DQ859889). PCR reactions using primer pairs YV1/YV4 and $\mathrm{a} 79 \mathrm{~F} / \mathrm{R}$ were positive for all isolates tested.

Eight isolates were grown on YDC agar, suspended in sterile water at a concentration of $10^{8}$ cells $/ \mathrm{ml}$ and infiltrated into leaves of tobacco (Nicotiana tabacum cv. 'Xanthi'), and petioles of cotyledon leaves of threeweek-old seedlings of sunflower ( $H$. апnиus cv. 'Flagman') and zucchini (Cucurbita pepo). Sterile water was applied as a negative control. All the inoculated tobacco leaves showed a hypersensitive reaction after 12 hours. The sunflower and zucchini plants were grown for 20 days in a glasshouse at $25 / 24^{\circ} \mathrm{C}$ (day/night). The plants were examined for wilting and a cross section was taken along the stem to observe the phloem. $84 \%$ of 65 inoculated sunflower and $30 \%$ of 27 zucchini plants developed wilting symptoms and phloem discoloration, while all the control plants remained free of symptoms.

CYVD caused by S. marcescens (Bruton et al., 2003) was first discovered in 1988 in the USA and is now spread throughout many states. The pathogen is vectored by the insect Anasa tristis. In the Russian Federation, plant diseases caused by bacteria of the genus Serratia have not been reported previously. This is the first report of the pathogen in the country and the first report of a new host plant, sunflower.

\section{Acknowledgements}

This work was supported by the USDA and US DTRA under the Cooperative Biological Engagement Program (ISTC project 3431).

\section{References}

Bruton BD, Mitchell F, Fletcher J, Pair SD, Wayadande A, Melcher U, Brady J, Bextine B, Popham TW, 2003. Serratia marcescens, a phloemcolonizing, squash bug-transmitted bacterium: causal agent of cucurbit yellow vine disease. Plant Disease 87, 937-944. http://dx.doi.org/10.1094/PDIS.2003.87.8.937

Schaad NW, Jones JB, Chun W, 2001. Laboratory Guide for Identification of Plant Pathogenic Bacteria. 3rd edition. St. Paul, MN, USA: APS Press.

Stackebrandt E, Liesack W, 1993. Nucleic acids and classification. In: Goodfellow M, O'Donnell AG, eds. Handbook of New Bacterial Systematics. London, UK: Academic Press, 152-189.

Young JM, Park DC, 2007. Relationships of plant pathogenic enterobacteria based on partial atpD, $\operatorname{car} A$, and $r e c A$ as individual and concatenated nucleotide and peptide sequences. Systematic and Applied Microbiology 30, 343-354. http://dx.doi.org/10.1016/j.syapm.2007.03.002 Zhang Q, Weyant R, Steigerwalt AG, White LA, Melcher U, Bruton BD, Pair SD, Mitchell FL, Fletcher J, 2003. Genotyping of Serratia marcescens strains associated with cucurbit yellow vine disease by repetitive elementsbased polymerase chain reaction and DNA-DNA hybridization.

Phytopathology 93, 1240-1246.

http://dx.doi.org/10.1094/PHYTO.2003.93.10.1240

To cite this report: Ignatov AN, Khodykina MV, Polityko VA, Sukhacheva MV, 2016. First report of Serratia marcescens causing yellow wilt disease on sunflower in Russia. New Disease Reports 33, 8. http://dx.doi.org/10.5197/j.2044-0588.2016.033.008

(c) 2016 The Authors This report was published on-line at www.ndrs.org.uk where high quality versions of the figures can be found. 